\title{
RNA Polymerase III IgG Antibody Measurement
}

National Cancer Institute

\section{Source}

National Cancer Institute. RNA Polymerase III Ig G Antibody Measurement. NCI

Thesaurus. Code C122147.

The determination of the amount of RNA polymerase III IgG antibody present in a sample. 